\title{
Erratum to: The visual amplification of goal- oriented movements counteracts acquired non-use in hemiparetic stroke patients
}

Belén Rubio Ballester ${ }^{1 *}$, Jens Nirme ${ }^{1}$, Esther Duarte ${ }^{2}$, Ampar Cuxart $^{3}$, Susana Rodriguez ${ }^{3}$, Paul Verschure ${ }^{1,4}$ and Armin Duff ${ }^{1}$

Unfortunately, in the original version of this article [1] the sentence "This project was supported through ERC project cDAC (FP7-IDEAS-ERC 341196), EC H2020 project socSMCs (H2020-EU.1.2.2. 641321) and MINECO project SANAR (Gobierno de España)" was missing from the acknowledgements.

The acknowledgements have been correctly included in full in this erratum.

\begin{abstract}
Acknowledgements
We would like to thank all patients who participated in this study. We also would like to gratefully acknowledge Irene Camacho, Estefanía Montiel, and Mirjam Stocker, for their assistance in recruiting and evaluating stroke patients. This project was supported through ERC project CDAC (FP7-IDEAS-ERC 341196), EC H2O20 project socSMCs (H2020-EU.1.2.2. 641321) and MINECO project SANAR (Gobierno de España).
\end{abstract}

\begin{abstract}
Author details
'Laboratory of Synthetic Perceptive, Emotive and Cognitive Systems, Center of Autonomous Systems and Neurorobotics, Pompeu Fabra, Roc Boronat, Barcelona, Spain. ${ }^{2}$ Servei de Medicina Física I Rehabilitació, Hospitals del Mar I l'Esperanç, Institut Hospital del Mar d'Investigacions Médiques, Barcelona, Spain. ${ }^{3}$ Servei de Medicina Física i Rehabilitació Hospital Universitari Vall dHebron, Barcelona, Spain. ${ }^{4}$ ICREA, Institució Catalana de Recerca i Estudis Avançats, Passeig Lluís Companys, Barcelona, Spain.
\end{abstract}

Received: 19 November 2015 Accepted: 19 November 2015

Published online: 27 November 2015

\section{Reference}

1. Rubio Ballester B, Nirme J, Duarte E, Cuxart A, Rodriguez S, Verschure P, et al. The visual amplification of goal-oriented movements counteracts acquired non-use in hemiparetic stroke patients. J Neuroeng Rehabil. 2015;12:50.

\footnotetext{
* Correspondence: belen.rubio@upf.edu

'Laboratory of Synthetic Perceptive, Emotive and Cognitive Systems, Center of Autonomous Systems and Neurorobotics, Pompeu Fabra, Roc Boronat, Barcelona, Spain

Full list of author information is available at the end of the article
}

Submit your next manuscript to BioMed Central and we will help you at every step:

- We accept pre-submission inquiries

- Our selector tool helps you to find the most relevant journal

- We provide round the clock customer support

- Convenient online submission

- Thorough peer review

- Inclusion in PubMed and all major indexing services

- Maximum visibility for your research

Submit your manuscript at

www.biomedcentral.com/submit 